\title{
Competitive Implications of Cross-Border Banking
}

\author{
by \\ Stijn Claessens \\ World Bank
}

\begin{abstract}
This paper reviews the recent literature on cross-border banking, with a focus on policy implications. Cross-border banking has increased sharply in recent decades, particularly in the form of entry, and has affected financial systems' development, access to financial services and stability. Reviewing the empirical literature, I find much, although not uniform, evidence that cross-border banking supports the development of an efficient and stable financial system that offers a wide access to quality financial services at low cost. However, as better financial systems have more cross-border banking, the relationship between cross-border banking and competitiveness has to be carefully judged. While developing countries have some special conditions, provided a minimum degree of oversight is in place, they experience effects similar to developed countries. There are some questions, though, on the impacts of cross-border banking on lending based on softer information and on stability. Relevant experiences from capital markets show that the degree of cross-border financial activities can affect local market sustainability and there can be path dependency when opening up to cross-border competition. Reviewing the fast changing landscape of financial services provision, I argue that cross-border banking highlights the increased importance of competition policy in financial services provision. This competition policy cannot be traditional, institutional based, but will need to resemble that used in other network industries. Furthermore, with globalization accelerating, competition policy will need to be global, supported by greater cross-border institutional collaboration and using the GATS process and the disciplines of the WTO. GATS can be of especial value to developing countries as it provides a binding, pro-competition framework that has proven more difficult to establish otherwise.
\end{abstract}

World Bank Policy Research Working Paper 3854, February 2006

The Policy Research Working Paper Series disseminates the findings of work in progress to encourage the exchange of ideas about development issues. An objective of the series is to get the findings out quickly, even if the presentations are less than fully polished. The papers carry the names of the authors and should be cited accordingly. The findings, interpretations, and conclusions expressed in this paper are entirely those of the authors. They do not necessarily represent the view of the World Bank, its Executive Directors, or the countries they represent. Policy Research Working Papers are available online at http://econ.worldbank.org.

Paper prepared for the Federal Reserve Bank of Chicago/World Bank conference on Cross-Border Banking: Regulatory Challenges, October 6-7, 2005. I would like to thank John Boyd and conference participants for comments. Contact: Stijn Claessens, Senior Adviser, Operations and Policy Department, Financial Sector Vice-Presidency, World Bank, 1818 H Street, N.W., Washington, D.C. 20433, phone 1- 202-473-3484, secretary 1- 202-473-3722, fax 1-202-522-2031, Email sclaessens@worldbank.org. 


\section{Introduction}

Cross-border banking has long been an important part of the trend towards increased globalization and financial integration. In terms of this paper, cross-border banking refers to both cross-border capital flows as well cross-border entry in banking. Cross-border capital flows have long been important drivers of financial integration. Particularly in the form of cross-border entry, cross-border banking has increased sharply in the last decade and has affected countries' financial systems in many ways and dimensions. Research has long studied the determinants and implications of cross-border capital flows and has started to analyze the determinants and cost and benefits of the recent wave of foreign entry in banking systems. In particular, a growing number of papers, using cross-country, individual and country bank evidence, have investigated the effects of foreign bank entry on local banking systems. The purpose of this paper is to review this literature, taking a broad view of crossborder banking as well as of its competitiveness implications, but focusing on the policy implications of the findings. In reviewing the literature, I focus on a number of aspects.

First are the determinants of cross-border banking. These determinants are important to identify as they point towards the countries and circumstances under which one can expect cross-border banking to occur-or the degree to which it might occur and affect the local financial systems. Many of the determinants of cross-border banking identified in the literature are as expected - countries' creditworthiness, quality of institutional environment and growth opportunities. Furthermore, there appears to be a regional or proximity bias, including clustering, in cross-border flows and banking. I highlight that these factors often correlate with the strength of the local financial system. In other words, good financial systems are more likely to also have more cross-border banking. As such, one can expect the determinants of cross-border banking to complicate the analysis of any competitiveness implications. In other words, it will be hard to separate any "implications" of cross-border banking on the local banking system, including its competitiveness, from the determinants of the strength of the local system.

Second, I review the costs and benefits associated with cross-border banking. In terms of impact, one can distinguish effects on the development and efficiency of the local financial system, on the access to financial services by firms and households, and on the stability of the local financial system and the overall economy. A growing number of papers have studied the effects of cross-border banking on efficiency and development, access to financial services and stability. I report that these studies find largely beneficial effects, although there are some questions regarding the impact on relationship type lending based on softer information, particularly in low-income countries, and on financial stability.

Third, I draw some lessons from the (more recently studied) integration in international capital markets. Here, the effects of integration and competition have been observed in several dimensions: micro-financial, e.g., lower cost of capital, higher rates of return on investment, more access to financing; institutional, e.g., better quality of local rules and enforcement thereof; and overall market development, e.g., beneficial as well as adverse effects on liquidity and prospects for a sustainable local market. The lessons from capital markets' financial integration and competition are relevant for cross-border banking not only as banking and capital markets are converging in many respects, but also as developments in capital markets tend to proceed faster than in banking. The capital markets' experiences suggest some specific lessons for cross-border banking: competitiveness' impacts extend 
beyond purely financial dimensions; there can be important impacts on overall market development; and there may be path dependency.

Fourth, I review more generally the fast changing global landscape of financial services provision. As financial systems, globally and nationally, absorb new technologies and distribution channels, see barriers among products and between markets being rapidly reduced, and as consolidation in many markets progresses, much is happening to the nature of the competition in financial services industries. I argue that these trends heighten the need to redefine competition policy broader than it has been done to date, including revisiting the special nature of banks. For all markets, I argue that there is a need to go beyond purely institutional approaches to competition policy-focusing on the contestability of entry and exit of players in a market - and beyond functional approaches - focusing on the level playing field in a market for a particular financial service. Rather, the need is to assure that the institutional environment for financial services provision is pro-competitive, implying (relatively) open access to all networks used, including payments, information and key distribution systems.

Fifth, I discuss the special circumstances of developing countries. Financial services industries in developing countries are undergoing changes similar to rest of the world. While institutional weaknesses in many developing countries are severe, they often represent deeper causes related to political economy factors related to the power of incumbents and associated with of a large public sector role. I argue that developing countries may benefit more than developed countries do from committing to a pro-competitive framework since credibility is more at a premium, and competition policy authorities are often weaker and have greater difficulty in implementing effective competition policy and resolving conflicts with prudential authorities.

Finally, I conclude with lessons for competition policy as they relate to financial services in general and to the role played by the WTO and regional free-trade types of arrangements. I argue that a horizontal approach negotiating to financial services is preferable. Under a horizontal approach, no single segment is negotiated separately but rather all services (and goods) are considered jointly. I highlight that this also means the prudential carve-out for financial services may need to be revised in scope and applicability. I also suggest that it will be useful to complement the forthcoming round of market access commitments in GATS with a set of pro-competitive principles of sound regulation. For developing countries the WTO/GATS can help in committing to pro-competition, especially as it relate to the institutional and functional approaches.

The structure of paper itself is as follows. I first define the forms of cross-border banking that I want to analyze: capital flows and entry by foreign banks. I also review what has been found to drive banking system integration, as (lack of) integration determines the scope for competitive implications. I next review how to define and measure the competitive effects of cross-border banking, focusing on several dimensions: efficiency, access, and stability. And I review studies on these aspects conducted so far. As an inter-mezzo, I review whether there are lessons from the recent global financial integration in capital markets for the (potential) competitiveness effects of cross-border banking. I then analyze the implications of broader trends in national and international financial markets, and particular what the changing competitive landscape implies for competition policy in some important dimensions. I discuss the special circumstances of developing countries and the role of the WTO/GATS next. Finally, I end with some areas of unknowns where further research can be useful. 


\section{Forms of cross-border banking, determinants and scope of consequences}

Forms of cross-border banking. Under the GATS framework, there are four forms of crossborder use or provision of (financial) services (Key, 2004). The first mode is cross-border supply, i.e., the traditional trade in good and services, which in the context of finance means capital flows. The second mode is consumption abroad, e.g., obtaining some financial services while traveling. The third mode is by commercial presence, i.e., the production of a good or service within the country, which means the foreign establishment in a host market. The fourth mode is delivery by the presence of persons in host country, e.g., solicitation of insurance products by agents traveling to the country. I focus on the first and third forms, i.e., the consumption or delivery of financial services produced by a financial institution located abroad or produced domestically by a foreign-owned financial institution. In financial services, these two forms are the most important forms of trade in financial services.

It is important to note that there are important interfaces between capital account liberalization and financial services liberalization, and thus between the two modes (Dobson and Jacquet, 1998). Obviously, some aspects of domestic financial services provision by foreign banks (mode 3) will be impeded if there is little capital account freedom. Vice-versa, the degree of capital account liberalization and ability to deliver financial services through capital flows will affect the incentives to establish local operations. Another aspect is the relationship between financial services liberalization and domestic (de-)regulation. The degree of domestic reform will affect the incentives of financial services providers' ability to produce and market financial services. This interface more generally relates to the issue of the determinants of cross-border banking. The degree and motivation of cross-border banking are important to acknowledge as they determine the scope for competitiveness effects. It is not just that without cross-border capital flows or entry, there will be no impact, but more generally the determinants condition the potential impact.

Determinants of cross-border banking. The literature has found capital flows and entry to be functions of the quality of countries' institutions, economic and financial openness, political stability and growth opportunities (see Eichengreen, 2000, for a review of capital flow determinants and Clarke et al. 2003 for a review of foreign bank entry). Financial centers seem to play a special role as they experience more entry relative to these factors (Buch, 2003; Buch and DeLong, 2004; see also Focaselli and Pozzolo, 2003). The literature has found capital flows to be motivated by perverse factors, e.g., moral hazard in the form of a safety net provided by the government (Dooley, 2000). For entry, besides these, more general factors, a residual role has been found for indirect barriers, such as limits on mergers and acquisitions (Berger, Buch, DeLong and DeYoung, 2004). Anecdotal evidence and industry studies (Financial Leaders Group 1997) show that these barriers can sometimes be quite subtle and raised by incumbents, as when access to the payments system is limited to incumbents through specific pricing or other policies (as has been argued in South Africa) or when there are limits on payments of interest on demand accounts (as was the case in France). The general point is that the determinants condition the possible effects of crossborder banking. Put differently, the competitiveness effects may be limited in those countries most in need of increased competition, for economic or political reasons, as cross-border banking is limited for exactly these countries (see further Berger forthcoming). 
Banking integration. While we would like to know the degree of effective financial integration as an input into any competitiveness study, in practice the degree of integration is hard to measure, even for developed countries where data are better than for many developing countries. When measured, it is typically done imperfectly using prices (e.g., interest rates) and quantities (e.g., actual capital flows or entry). Among developed countries that otherwise face limited barriers and otherwise well functioning institutions, such the EU, integration has been found to be high in wholesale banking and certain areas of corporate finance, modest in relationship, and low in retail banking (CEPR, 2005). For example, Dermine (forthcoming) shows that in terms of quantities, cross-border banking penetration in the EU has been the least in retail banking. In terms of prices, differences in spreads have been found to be the lowest in corporate banking and the highest in retail markets (ECB, 2005; see also Baele et al. 2004). For the most part, integration has thus been the highest where theory predicts, even when some barriers to integration remain. The competitiveness effects have been correspondingly, at least at face value, i.e., less in naturally more "segmented" markets, such as retail and relationship lending. Note that one needs to add "at face value" since theory suggests - and empirics show it is difficult to determine the competitiveness of some financial markets.

Consistent with their weaker economic fundamentals and institutions, the degree of banking integration for developing countries is more limited. The competitive impact of capital flows is often (further) limited to a subset of borrowers - highly rated corporations, financial institutions, possibly connected to government or political powers - and a subset of depositors and lenders (e.g., capital flight) as typically only those have international access (Claessens and Perotti, 2005). For banking entry in developing countries, though, competitive effects possibly cover a much wider spectrum of borrowers, lenders and others, as entry can be large (50\% or more of market share is not uncommon in emerging markets; see Hohl and Remolona, forthcoming and Levy-Yeyati and Micco 2003). At the same time, the economic environments in developing countries are not always stable and financial and corporate sector reform processes are often underway or incomplete. This means the entry impact effects can be harder to discern from other factors, e.g., are the changes due to increases in competition, changes in governance, regulatory and supervisory improvements, or other reforms?

Possible competitive effects. What types of effects can one distinguish? I consider three dimensions: development and efficiency, access, and stability. Under the first, development and efficiency, I consider questions like: is the system more developed, e.g., is it larger, does it provide better quality financial products/services; is it more efficient, i.e., exhibit a lower cost of financial intermediation, is it less profitable; and is it closer to some competitive benchmark? Under access, I consider whether access to financing, particularly by smaller firms and poorer individuals, but also in general for households, large firms and other agents is improved, in terms of volume and costs. And in terms of stability, I consider whether the banking system has less instability, fewer financial crises and is generally more robust and its financial integrity higher. I look at all these dimensions as they can be important relationships among them, making analyzing any individually not complete.

Theory. It is useful to consider what to expect given theory on some of these dimensions. First, the general competition and contestability theory suggests that the market structure and the actual degree of entry or exit are not the most important factors in determining competition. The degree of contestability, rather than actual entry, matters for competitiveness (Baumol, Panzar, and Willig, 1982). Furthermore, competition can be expected to affect several dimensions: not only efficiency and costs, but also the incentives of 
institutions and markets to innovate. Financial sector specific theory on competition effects adds to this some additional considerations (see Claessens and Laeven, 2005 for a review). It has been found that the structure of systems can matter, but in many ways, including the ownership of the entrants and incumbents, the size and the degree of financial conglomeration (that is, the mixture of banking and other forms of financial services, such as insurance and investment banking). It has also analyzed how access depends on the franchise value of financial institutions and how the general degree of competition can negatively or positively affect access. With too much competition, for example, banks may be less inclined to invest in relationship lending (Rajan, 1992). Because of hold-up problems, however, too little competition may tie borrowers too much to an individual institution, making the borrower less willing to enter a relationship (Petersen and Rajan, 1995 and Boot and Thakor, 2000).

The quality of information interacts with the size and structure of the banking system. There is evidence, for example, for the U.S. that consolidation has led to a greater distance and thereby to less lending to more opaque SMEs (Berger, Miller, Petersen, Rajan and Stein, 2005; see also Carow, Kane and Marayaman 2004, Karceski, Ongena and Smith 2005, Sapienza 2002, Degryse and, Masschelein and Mitchell, 2005). The fact that too much competition can undermine stability and lead to financial crises has been often argued (Allen and Gale, 2004 review), although difficult to document systematically (see Beck, DermirgucKunt and Levine, 2002). These complex relationships and tradeoffs among competition, financial system performance, access to financing, stability, and finally growth already make it clear that it is not sufficient to analyze a narrow concept of competitiveness alone.

The theory on the effects of competition in financial services has shown some further complications. Some have highlighted that competition is partly endogenous as financial institutions invest in technology and relationships (e.g., Hauswald and Marguez, 2004). This in turns means there are often ambiguous effects of technological innovations, access to information, and the dynamic pattern of entry and exit on competition, access, stability and efficiency (e.g., Dell'Ariccia and Marquez, 2004, Hauswald and Marquez, 2003 and Marquez, 2002). The effects are further complicated by the fact that network effects exist in many supply, demand or distribution aspects. As for other network industries, this is making competition more complex (Claessens, Dobos, Klingebiel and Laeven, 2003). Importantly, financial services industries are continuously changing-due to removal of barriers, globalization, increased role of non-bank financial institutions, technological progress and increased importance of networks, which is affecting the degree and type of competition, something I will analyze further below in section 3.

Empirics. Although theory alone is giving mixed insights into the effects of cross-border banking on competition, the empirical findings are fairly clear. In terms of development and efficiency, competition through cross-border capital flows has led to lower cost of capital for borrowers, higher rates of return for lenders, i.e., lower margins and lower costs of financial intermediation (Agénor, 2001, Bekaert and Harvey, 2003), spuring growth (Bekaert, Harvery and Lundblad, 2005). Interestingly, there is some evidence that foreign banks' international activities are not necessarily more profitable. (DeYoung and Nolle, 1996 and Chang, Hasan and Hunter, 1998), involving possibly some cross-subsidies (as has been noted for Japanese banks; see Hasan and Hunter, 1996 and Peek, Rosengren and Kasirye 1999) or evidence that diversification benefits of international activities make lower profitability still attractive (Berger, DeYoung, Genay and Udell, 2000). The effects of cross-border capital flows on access are found to be positive as well, although as noted increased access has largely been 
for selected groups of borrowers. Finally, the effects on stability of international capital flows have generally been found to be favorable — as international financial integration allows for greater international specialization and diversification (e.g., Obstfeld, 1998). Of course, international capital flows can add to financial risks, among others, through contagion (Dornbusch, Park and Claessens, 2000 and Claessens and Forbes, 2001).

The entry of foreign banks has generally had favorable effects on the development and efficiency of domestic, host banking systems (Micco, Panizza and Yanez, 2004; Mian, 2003). These generally positive results have occurred through various channels. Lower costs of financial intermediation (measured in the forms of margins, spreads, overheads) and lower profitability have generally been documented (see Claessens, Demirguc-Kunt, and Huizinga, 2001 and follow-up studies, e.g., Berger, Clarke, Cull, Klapper and Udell, 2005). Also, researchers have found some evidence of a better quality of financial intermediation, e.g., as one observes less loan-loss provisioning with more foreign entry beneficial (Martinez-Peria and Mody, 2004). The qualitative aspects have by nature been harder to document, but have possibly been most important. These include the emergence of new, more diverse products, the greater use of technologies, and the spillovers of know-how (e.g., as people learn new skills in foreign banks and migrate over time to the local banks). An additional channel has been pressures of foreign banks to improve regulation and supervision, increase transparency, etc., and more generally be a catalyst for reform (see further Levine 1996 and Dobson, 2005, for reviews).

The effects of the entry of foreign banks on development and efficiency appear to depend, though, on some conditions. The general development and any remaining barriers can hinder the effectiveness of foreign banks (Garcia-Herrero and Martinez Peria, 2005; DemirgucKunt, Laeven and Levine, 2004). Also, the relative size of foreign banks' entry seems to matter. With more limited entry (as a share of the total host banking system), fewer spillovers seem to arise, suggesting some threshold effect (Claessens and Lee, 2003). In terms of individual foreign bank characteristics, it seems that larger banks are associated with greater effects on access for SMEs, perhaps as they are more committed to the market, while smaller banks are more niche players (Clarke et al. 2005). The health of both the home banks as well as the local host bank matters, with the healthier banks showing better credit growth (Dages Goldberg and Kinney, 2000; see also Haber and Musacchio, 2005 and de Haas and van Lelyveld, 2005).

It should be noted that these effects of the entry of foreign banks are not necessarily competitiveness effects since the studies reviewed so far are not tests of formal competition models. Fully specified empirical competitiveness studies are scarce, with mostly single country studies, but only a few cross-country studies (Berger, forthcoming reviews). To the extent available, however, cross-country evidence using formal empirical contestability tests suggests that foreign bank ownership is the most consistent factor associated with improved competitiveness of local banking systems (Claessens and Laeven, 2004). Next in importance are less severe entry and activity restrictions on banks. This same study suggests that there is little evidence that the structure of banking system matters in terms of competitiveness. Bank concentration and competitiveness are actually sometimes positively correlated, i.e., more concentrated banking systems exhibit more competitive behavior and the number of banks is never positively, and sometimes even negatively related to measures of competitiveness, i.e., more banks make for less competition. This confirms the importance of contestable system rather than a certain structure. 
The effects on access by foreign banks can be separated in terms of access to foreign capital and access to domestic financing. Access to international financing is surely enhanced for some borrowers and lenders. Indeed, evidence suggests that both in normal times, but especially during time of crises, borrowers have enhanced access to finance with more foreign banks present (Goldberg, 2002). In terms of access to domestic capital, maybe in part since this is being more recently studied, the findings are not as clear. Generally, though, it has been found that access is enhanced by direct provision by foreign banks and indirectly by putting pressure on local banks (e.g., more competition and stability driving local banks to provide more access). It has been found, for example, that firms report financing obstacles to be lower with more foreign banks, that even small and medium enterprises (SMEs) benefit and no evidence has been found that these SMEs are harmed by the presence of foreign banks (Clarke et al. 2001 see also Beck, Demirguc-Kunt and Maksimovic, 2004). There is some evidence to the contrary though. Detragiache, Gupta and Tressel (2005) for example, find that foreign banks presence in low-income countries leads to a reduction in credit and higher operating costs.

Foreign banks seem to lead to more entrepreneurial activity, although the effects are lesser for smaller firms. Interesting, more "connected" firms, i.e., those having access based on non-economic factors, seem to suffer in access from foreign banks, which would be a positive effect (Giannetti and Ongena, 2005). Two aspects are not yet well known: whether the effects come about in a mostly direct or indirect way; and whether entry is less beneficial in softerinformation lending as foreign banks may rely more on hard information to do their lending (see Berger, Klapper and Udell, 2001 for some evidence). These aspects are still to be investigated further.

Finally, the effects of entry of foreign banks on stability are generally found to be positive. There appears to be less risks of financial crises, and banks, foreign as well as domestic, display higher provisioning, less non-performing loans, suggesting better quality lending (Demirguc-Kunt, Min and Levine, 1998 and Barth, Caprio and Levine, 2001). There is also evidence of less pro-cyclical lending behavior of the local operations of foreign banks relative to the cross-border operations of foreign banks (Goldberg, 2005) and lower sensitivity to the risk of financial contagion (Goldberg, 2002). There are, however, some possible negative effects. These include negative effects on franchise value, although often hard to determine given recent entry in many markets (Boyd, DeNicolo, and Smith, forthcoming). There can also be the risk of undiversified home countries (Buch, Carstensen and Schertler, 2005), which have to be weighted against the risk of an undiversified banking system without entry. Then there is the risk of new technologies and new financial instruments being introduced pre-maturely. Again, these risks may arise in principle, but are hard to quantify. Finally, there is the risk of easier capital flows, possibly capital flight, as a consequence of banks that have greater access to international financial markets. And there are the risks to the home countries (Cetorelli and Golberg forthcoming).

Much of these empirical findings on cross-border banking have to be qualified by the fact that, even without formal barriers, financial integration remains imperfect. One observes that even in fully integrated markets, such as the U.S. or increasingly so the EU, that there still is a familiarity bias in capital flows and entry decisions, e.g., more investment and entry closer to home. This means that the competitiveness effects can remain limited to some markets, regions or market segments (Mian, forthcoming). Of course, any further removal of barriers may still facilitate entry. While evidence of immiserizing effects of foreign banks entry in the presence of distortions is limited, many observers (e.g., CEPR, 2005) and market 
participants have argued that achieving the full gains from entry requires more (minimal) harmonization of regulations, legal and other institutional infrastructure.

Furthermore, it is important to consider the interactions between capital account liberalization, financial services liberalization and domestic deregulation. Generally, liberalizing along all three dimensions, is considered mutually reinforcing. There are, however, issues of consistency and coherence between the three forms of liberalization to consider. Financial services liberalization can require some degree of capital account liberalization as foreign banks need access to international financial markets to operate effectively. Domestic deregulation and capital account liberalization can both involve the removal of lending restrictions, which needs to be done in a consistent fashion across the two forms. Inconsistencies, for example, when firms are allowed to access certain forms of international capital freely, while still being restricted in their borrowing domestically, can lead to the buildup of external vulnerabilities.

Cross-border banking through capital flows and through entry can be alternative to reach a market (Buch and Lipppner, 2004) and tradeoffs can arise. Using data from Italian, Spanish and US banks, Garcia-Herrero and Martinez Peria (2005) found that foreign banks open branches in countries with better profit opportunities and greater "banking freedom," that is, countries that do not impose restrictions on bank activities, controls on foreign currency lending or high taxes on banking. In smaller, less secure developing markets, though, banks rely more on cross border lending. There is also some evidence that stock markets liberalization before financial services liberalization increases the benefits of foreign banks, but that capital account liberalization first reduces the benefits (Bayrakta and Yang. 2004 see also Claessens and Glaessner, 1999).

Lessons from capital markets. A short intermezzo useful here concerns the lessons from capital markets' integration for cross-border banking. Capital markets, both equity and bond markets, have for long time experienced much cross-border financial flows and in the recent decades have also seen more services being consumed cross-border (for example, in the form of the listing and trading of securities at international exchanges). And there has been some foreign entry in capital markets in the last few years. Capital markets integration is not the main topic here, but still can provide some useful lessons for three reasons. One, for a number of reasons, including easier adoption of technology, capital markets are evolving faster than banking markets are. As such, one may learn from capital markets for changes coming to banking markets. Second, and more debatable, capital markets are less subject today to natural and policy barriers than banking markets are. The traded nature of assets and the lesser importance of soft information, for example, make cross-border trading in securities easier than in banking products. Financial integration in capital markets is then often also deeper than in cross-border banking. And third, there has been some convergence of banking to capital markets in terms of products and approaches, as, for example, in the form of credit derivatives.

While there are many similarities between capital markets and cross-border banking, there are some important differences. Not only are barriers (institutional and technological) less in capital markets than in banking, integration appears to a lesser degree than for banking markets a function of the quality of institutional environment. One has, for example, seen near complete price integration in the capital markets of some more developed emerging markets, while cross-border banking flows still remain limited for the same countries. There are also more distinct scale effects in capital markets, more so than in banking, with small 
scale hindering the development of the local markets and encouraging internationalization of financial services (Claessens, Klingebiel and Schmukler, 2005). Most importantly, the implications of financial integration in capital markets are experienced not only in supply and demand dimensions but also in institutional aspects. In international capital markets, as for cross-border banking, suppliers and demanders benefit from a lower cost of capital, lower trading costs, more liquidity, higher returns, greater quantity of external financing, etc. In equity markets, however, there is also evidence that the institutional environment is affected as a consequence of competition. Generally, the local institutional environment improves, i.e., when faced with competition, countries engage in a race to the top more likely than to the bottom (Coffee, 1999). In terms of impact on overall market development and prospects, however, it appears that local liquidity declines, not just for stocks listed and traded abroad, but also for the local-only stocks (Levine and Schmukler, 2003). Competition can thus have some negative effects on the overall development of local capital markets.

The lessons from capital markets for cross-border banking would be that competition effects can be broad. Competition can affect efficiency and access, but also the evolution of rules and institutions. Furthermore, competition can even affect the presence of markets. Since scale effects appear important in capital markets, small local markets may be at risk from competition, including through negatively affecting the scope for the development of local services supporting capital markets (e.g., accounting and investment banking services). As such there can also be path dependency, e.g., the development of local markets prior to introducing competition might provide greater scope for ending up with functioning local markets. Arguments for infant industries are very tricky, though, given political economy factors, and as such may not provide the desired results.

\section{Changing competitive landscape}

So far, I have analyzed the forces that drive cross-border banking and the impact cross-border banking can have on domestic banking markets. While I have highlighted that many of the impacts of cross-border banking are similar to those usually subscribed to increased competition, there are some important differences, particularly in turns of access, stability and market development. This analysis was, however, largely still within the paradigm of the typical goods markets and a relatively stable global financial system. But competition in the financial sector can be very different from that in other goods or services markets. Furthermore, financial services industries are in flux and the nature of competition is changing as a consequence. This has implications not only for the nature of competition, but also for competition policy. In this section, I will analyze the basic difficulties with applying competition policy in finance as well as the forces for change in financial services industries today, ending up with some suggestions on how competition policy might need to be adapted.

Competition in finance. Competition policy in financial services provision is complex (see Vives 2001 for a review). The presence of large sunk costs and high fixed costs in the production of financial services mean significant first mover and scale advantages, possibly leading to natural monopoly and market power. Large switching costs mean that customers do not easily change financial services providers and make the adoption of new technologies exhibit critical mass properties. Financial services provision also involves the use of a great number of networks, such as payments, distribution and information systems. This means barriers to entry can arise due to a lack of access to essential services. More general, network externalities can complicate the application of competition policy. Finally, the "special 
nature” of financial sector, with its emphasis on financial stability has always meant that competition policy was considered more complicated. "Free entry", for example, even when subject to fitness test, has generally been considered to pose risks to financial stability as it would undermine franchise value. While arguably these arguments are less relevant today — as many financial services can be provided by non-bank financial institutions and the role of banks as liquidity providers is less crucial today - it still affects the application of competition policy in finance in practice.

In addition to these complications, recent trends have made competition, and competition policy, more complex (see Claessens, Dobos, Klingebiel and Laeven, 2003 for a review). For one, market and product definitions have become (more) difficult. It is trite, but nevertheless very important from a competition policy point of view to state that financial markets today are global in nature, making any application of competition policy to national markets of lesser value than two decades ago. Second, markets are rapidly consolidating around the world (Berger, Demsetz and Strahan, 1999).

In addition, the definition of a specific financial service and its market has become more complicated, affecting competition policy. Today, for example, there are little differences between the market for pension and that for assets management services. And with many non-financial institutions providing (near) banking and other financial services, the boundary between non-bank financial institutions and banks has become blurred. More generally, the production of financial services has changed in many ways, with large investments in information technology and brand name necessary to operate effectively and to gain scale. There are also some forces towards vertical integration in some aspects, especially in capital markets (e.g., integration of trading systems with clearing and settlement), while other forces push towards more separation (e.g., clarity in functions) or horizontal consolidation (e.g., economies of scale). In addition, there are increasing links between banking and commerce (e.g., between banking and telecommunications).

Revisit competition policy. These changes point to a need to revisit competition policy in the financial sector. I suggest that the "new" competition policy combines three approaches: an institutional approach, to assure contestable markets by entry/exit of institutions, domestic and cross-border; a functional approach, to assure contestable markets by leveling the playing field across similar financial products (in all dimensions); and a production approach, to assure efficiently provided and equally accessible and affordable network services (information, distribution, settlement, clearing, payment, etc.) and to take into account any network externalities. Combined, these approaches can make competition policy resemble that in other network industries, e.g., telecoms. So far, however, only the institutional and somewhat the functional approaches have been used. I will next expand on these three approaches (see further Claessens 2003 for more detail).

Institutional approach. The institutional approach to competition means that the entry and exit regime for different type of financial institutions should be pro-competitive, or at least as contestable as possible after considering issues arising from financial stability. As in other sectors, applying the institutional approach in the financial sector involves, among others, a review of entry and exit barriers for a market at a regional, country, or, global level; a review of actual entry and exit decisions, mergers and acquisitions of financial institutions; and investigations of market power and dominance of institutions. As noted above, this approach is generally accepted, but is nevertheless not always used, especially not at the global level. 
Functional approach. The functional approach uses the same concept of contestable markets, except it applies it to a specific service, rather than to a set of financial institutions. The functional approach implies a need to level the playing field for each financial service and between similar types of financial services across all types of providers. It means a proper entry and exit regime for each financial service and avoiding differences in the regulatory treatment of similar types of financial services. Few countries have adopted this approach. And even when tried in earnest, the principle of a level-playing field across functions is difficult to put in practice. One reason is that the substitutability between specific financial services can be high in most dimensions, but involve subtle differences in some dimensions, such as credit risks or access to the safety net. Whether remaining differences are distortionary will often be very difficult to establish. Furthermore, historical differences can be difficult to correct as many other aspects come into play. ${ }^{1}$

Even when distortions in treatment across products have been minimized, however, it will be difficult to assess whether markets for specific financial products are fully competitive or contestable. One reason is that financial institutions typically bundle financial services together and/or cross-subsidize services. This can be because financial institutions derive their comparative advantage from the bundle of services they provide, rather than from any specific individual service. But, it may also be because regulatory or other advantages (e.g., access to a distribution network) allow the financial institution to provide the bundle of services in a way more advantageous than a single service provider can. Open entry in one market segment may as a consequence not guarantee a competitive market for each specific product. Or it can be that predatory cross-subsidization in the presence of natural entry barriers gives existing institutions an unfair advantage, allowing them to build up a market share. More generally, given the network properties analyzed, it is difficult to ascertain that there are no anti-competitive barriers remaining. It is therefore necessary to go beyond the institutional and functional approaches with a more production-based approach to competition policy.

Production approach. The production approach would mean that the various inputs, including network services, required for the production and distribution of financial services need to be available to all interested in using them, be fairly and uniformly priced and efficiently provided. For no part of a specific financial service production and distribution chain, should there be any undue barriers or unfair pricing. For most inputs (labor, services, etc.), this in turn simply requires competitive supply markets. Since the production and distribution of financial services rely much on common infrastructure with network properties, however, this approach requires more. Specifically, it requires an "efficient" market infrastructure, which itself is not an easily defined concept, in part as many elements of financial infrastructure have been subject to changes recently.

The market infrastructure for financial services involves many parts, such as trading systems, payment and clearing systems, ATM systems, and information systems. Differences are many, but competition issues can arise from differences in access, ownership-public versus

\footnotetext{
${ }^{1}$ Even when attempts have been made to level the playing field for financial service providers and across financial services, regulatory and other differences may continue to create barriers to full competition. Standards may conflict, for example, such as the need to require capital for local branches of foreign banks, but not for branches of domestic banks. Information requirements may differ by product, e.g., although otherwise similar, securities markets products may require more information disclosure than pension products. Differences in the tax treatment between pension and other forms of savings can be large, although they are in many ways equivalent financial instruments.
} 
private ownership - and forms of control, oversight, and corporate governance. The commonly shared infrastructure of a payments system, for example, can be run by a central bank, by banks themselves, or by a third party. Choices further vary between for-profit and not-for-profit organizations, and related, mutual and demutualized structures. Stock exchanges, for example, can be organized as mutual, not-for-profit organizations or as forprofit corporations. The various oversight structures - self-regulatory, government or purely private arrangements — can vary, by explicit design or historical consequences.

Each of these differences can give rise to its own set of competition policy issues. Private ownership of the market infrastructure may lead to direct forms of rent-seeking by the owners. Self regulation of a market may lead to rules that favor insiders. Competition is, however, only one of the dimensions according to which one can evaluate the various arrangements for the provision of market infrastructure services and the recent changes. Dimensions such as the efficiency of providing relevant (supportive) services, risk management, integrity, incentives to innovate and upgrade, are often equally or more relevant. The general assessment is that the trend toward demutualization and privatization of stock markets, for example, has led to efficiency gains in the delivery of these services, without necessarily compromising (and often even enhancing) the objectives of proper risk management, integrity, and stability. But whether the recent changes are also always procompetitive is not clear, at least not as of yet, as little time has passed and research been very limited. Similar lack of clarity exists with respect to competition implications of the new alternative trading systems for stocks and other financial assets. More generally, the type of competition policies applicable to the market structure supporting forms of financial services is not yet clear.

\section{The special issues of developing countries}

In many ways, financial services industries in all countries have been subject to similar trends. Despite differences among countries-including factors such as the state of the financial system, readiness of the telecommunications infrastructure and the quality of the regulatory framework - there is much commonality and convergence in the way financial services industries are being reshaped. In securities markets, global trading is becoming the norm. Increased connectivity has accelerated the migration of securities trading and capital raising from emerging markets to a few global financial centers. In banking, consolidation is proceeding in many markets and integrated financial service provision has become the norm around the world.

Despite similarities in the evolution of financial services industries around the world, there remain large differences among countries in terms of overall development, the stages of their financial sector development, and the quality of their institutional frameworks. This raises the question whether there is a need to approach the issues of cross-border banking and competition policy differently by level of development.

For a variety of reasons, countries are at different level of development of their regulatory and supervisory capacity, quality of legal and judicial systems, and other institutional dimensions. Reaping the full gains of cross-border banking can require a certain minimum level of financial sector regulation and supervision. Many of developing countries' deficiencies are being identified in the assessment of compliance with international standards. Deficiencies in each of these areas are expected to be addressed over time in the follow-up 
and through general pressures associated with this process (such as through disclosure of deficiencies and pressures from peers and investors).

These reforms will take time. Furthermore, one has to acknowledge that there will often be deeper reasons why failures in regulation and supervision do not allow developing countries to reap the full benefits of their liberalization efforts. In particular, the failure of countries to take appropriate regulatory actions when liberalizing often relates to political economy reasons, involving often moral hazard and (too) extensive forms of deposit insurance. To change this will require achieving greater political openness itself a gradual process in many cases (Barth, Caprio and Levine, 2005). Nevertheless, one should consider how reforms in cross-border banking could help overcome some of these political economy constraints. Entry by foreign financial institutions will often bring with it not only foreign expertise, but can also reduce political pressures on the supervisory system. Similarly, broadening the scope of institutions able to provide financial services can reduce the political influence of incumbent banks.

Beyond the need for a consistent approach in the three forms of liberalization and the need to deal with political economy factors, arguably there are no fixed preconditions to allow effective internationalization of financial services. Countries with weak and strong regulation and supervision can both do well under large foreign entry; in the first case, foreign entry brings with it improved regulation and supervision, enhancing the quality of the overall domestic sector; in the second case, strong domestic regulation and supervision assure that entry does not lead to any concerns. It may be that the intermediate cases of moderately developed frameworks present the most risks as foreign financial institutions compete away franchise value of incumbents, thus creating incentives for imprudent behavior, and as domestic and foreign investors misjudge the stability of the system and the robustness of the regulatory response. In such cases, good closure rules for weak financial institutions and quantitative restrictions on financial exposures may be the most appropriate response while liberalizing.

Country conditions surely have relevance, however, for the way in which competition policy, including the disciplines associated with GATS/WTO, is conducted. In spite of reforms, many developing countries' financial sectors are still characterized by a lack of "effective" competition. They may have a quite concentrated market structure, extensive links between financial institutions and corporations, and a high ultimate ownership concentration of the financial sector. While in principle many developing countries are open today, entry by foreign financial institutions may be limited to some niche areas, in part because of country risk perceptions. Important, incumbent financial institutions may have a lock on networks essential for financial services provision. Existing incumbents may block new initiatives via a variety of means. The net results will be less pressure to reduce costs, to improve the quality of financial services and to move down the credit scale into lower-income retail and small-enterprise lending.

While again it is difficult to generalize on how competition policy ought to be differentiated by level of development, it is likely more important for developing countries to include competition issues when designing reforms including changes to the payments system, credit information arrangements, and telecom regulatory and legal frameworks. Specifically, one needs to be careful in the design of networks, whether they involve financial service specific systems only or are telecom related as these can become important barriers to entry, including for foreign banks. In the area of retail payments, for example, the use of a third party 
provider (not a consortium of banks) for the provision of different forms of retail payment services could be more appropriate from a competition point of view when the market structure is very concentrated.

An effective competition commission is critical, but that will require adequate support, jurisdiction and backing vis-à-vis other supervisory agencies. In case of many developing countries, the overall capacity and independence of competition authorities is limited and proper enforcement tools are missing. Often, political support will be lacking and conflicts may exist between the competition policy agency and the agency that deals with prudential regulation. Also, a case for more restrictions on cross-holdings can be made, particularly in smaller developing countries. Limits on groups and banking-commerce may be necessary to assure effective competition.

\section{The role of GATS and WTO}

The GATS can be an important force for a more pro-competition policy in financial services. The past financial services negotiations, however, have been arduous and extended (Sorsa, 1997). Final success has arguably been relatively limited as many countries have commitments that are much less binding than their existing practices. In others words, most countries have not used the process to bind themselves to an (accelerated) process of liberalization. In part, this outcome has arisen because the approach to date for financial services has been sector-specific and largely outside the normal GATS-negotiations (Kono et al 1997 and Key, 2004).

Going forward, similar to other goods and services, a horizontal approach is preferable for financial services given the increased inputs from other sectors in the production and distribution of financial services, including those from networks industries such as telecommunications. Liberalizing financial services industries alone may not lead to the full possible gains if other sectors do not liberalize equally. A horizontal approach is also more feasible today as financial services have become less special and the horizontal approach is thus less likely to lead to conflicts with prudential concerns. A key argument for a horizontal approach, however, is that political economy factors, that are so prevalent in financial services, have dominated the negotiation outcome. When there was no ability to tradeoff interests with those in other sectors, the political powers led to a limited liberalization. As financial services are increasingly being recognized as essential inputs in overall economic production, the support from other sectors for efficient financial services provision, and consequently for liberalization, has increased, making a horizontal approach more attractive.

Applying the horizontal approach to financial services liberalization may require a revisiting of the prudential carve-out of GATS (Sauve, 2002). The carve-out has already been used as an argument to keep financial services out of the Uruguay Round negotiations. There are some issues as to the interpretation of the scope of the carve-out. Under some interpretations, the carve-out cannot be used to evade other GATS commitments and needs to be aimed primarily at prudential regulation. Even with this strict interpretation, however, the issue remains what constitutes justifiable prudential regulation. On one hand, a more standard view on prudential regulation has developed through, among others, the promulgation of international banking and other standards, thus reducing the likelihood of differences in frameworks leading to non-trade barriers. At the same time, there may be a need to rethink prudential regulation given changes in the financial services industries globally. As noted, in 
many countries regulation has stifled competition and countries political economy may mean that more rules will encourage this behavior. The current emphasis on global standards, as part of the new international financial architecture, implies that there are legitimate concerns that the approach will overshoot in concerns for safety, soundness and stability at the expense of concerns over free trade in financial services.

The potential anti-competitive way in which the prudential carve-out can be applied does not imply that it needs to be removed fully. For one, it is likely to be used sparingly. Countries realize the reputation costs of invoking the carve-out and applying prudential regulation in an anti-competitive way. Particularly in the context of developing countries, investors will look for signs of credibility and invoking the carve-out will provide the opposite signal, especially when in a financial crisis. It is also unclear what type of regulations can reduce risks of financial contagion and volatility, arguably the more likely causes of crises going forward. Useful regulations will include some prudential banking systems regulations (e.g., requiring certain loan-loss provisioning), but they could also be more macro-economic in nature (e.g., limiting exposures to certain sectors), or aimed specifically at some balance-of-payments objectives (e.g., restrictions or taxes imposed on short-term capital flows). Whether these fall (or ought to fall) under the prudential carve-out is unclear. Nevertheless, there might be circumstances when a form of carve-out will be useful, although it can be more circumscribed than currently formulated.

In addition to assessing the scope of the prudential carve-out under GATS, it will be useful to complement the forthcoming round of market access commitments in GATS with a set of pro-competitive principles of sound regulation. Proposals in this respect have been made by many in the financial services industry. They center around commitments on improved transparency and regulatory reform, including transparent domestic rules and administrative procedures. This emphasis on increased transparency would be consistent with the general need highlighted in this paper that trade liberalization needs to be complemented with a more active competition policy.

\section{Areas lesser known}

Rather than present conclusions, I like to raise some areas that are less well-known. A number of these will be taken up in the other parts of the volume. I am raising them here as they can also have competitive impact. One is what to do to further foreign bank entry. If, as evidence suggests, entry by foreign banks can be useful, are there specific measures countries can put in place to attract foreign banks? Since there is also some evidence that the size of banks and the nature of the home country affect the behavior of entrants, it can be suggested that policy makers try to affect the size and home country of foreign banks entering. Furthermore, since lending can been hindered by the more formal approaches used by foreign banks, and distance more generally creates obstacles, it is tempting to suggest using a different regulatory approach to foreign banks' international operations. This, of course, is quite difficult and can create uneven approaches. This seems to deserve some further research. Also, can the right type of banks—size, host, diversified — specifically be attracted at all? And if so, are such, possible preferential treatments consistent with the WTOprinciples? In terms of the overall sequence of reforms - capital account liberalization, financial services liberalization, domestic deregulation - there are questions on sequence to be followed that maximizes the impact of foreign banks. I am skeptical research can cast 
much light on this in general, but nevertheless one can try to review some case studies as to their experiences with sequencing.

A broader question is what to do in small economies. Clearly, there are many scale issues to consider here beyond cross-border banking and foreign banks entry specifically. It raises the "economies of scale" of an own currency, regulation and supervision, etc. But one can try to address whether there are more special approaches, or sequences to be followed. There are experiences of countries like the Baltics that adopted at the same time currency boards, had large cross-border banking and harmonized rules as they got ready to enter the EU. Perhaps these and other small economies experiences are relevant to review. Furthermore, regional solutions and some of the arrangements in the African currency unions on common institutional infrastructures (stock exchanges and regulation and supervision) may be relevant to review. Also, might there be ways to open up particular aspects of financial services provision chain that are more suited to small economies? For example, in the area of banking, could gross value payments system be outsourced to foreign markets, while retail payments system are developed domestically? Again, these are issues that could have implications for competition.

The minimal requirements on rules and the necessary degree of harmonization of rules and practices are typically considered regulation and supervision issues. Yet, there is a competitiveness angle to them as well. Apart from the need to assure contestability, there could also be an argument to adapt rules given the special focus of foreign banks. If indeed foreign banks focus more on hard-information, foreign banks may be more conservative in their local lending behavior in developing countries, thus potentially making less of a contribution. This behavior can be part of their general practices (see de Haas and Naaborg, 2005) — and should thus not be discouraged (Stein, 2002), but could in part also because they apply their de-facto more strict home standards (whether Basel II, AML, etc.) to their local lending operations. To the extent this more formal approach creates too great a distance from the borrower, and undermines productive lending, should the rules consequently be adopted? Put differently, there may be some specific regulatory responses that increase the competitive impact of entry of foreign banks. For example, whether subsidiaries or branches are allowed for foreign banks can perhaps consider the development and competitiveness impact. ${ }^{2}$ More generally, is there an argument to avoid overregulation of foreign banks, operations and if so what regulatory elements specifically can be adjusted?

Finally, what does the "new" view of competition policy mean for the tools for identifying and addressing competition issues? Clearly, the tools typically used to date are quite limited (Herfindahl/or concentration indexes) and need to be enhanced. Yet, the analytical tools developed for measuring competition in financial services industries are hard to apply empirically. What to use in practice? Related, what is the specific role of WTO/GATS and regional free-trade agreements (FTA) in this process? How can GATS/FTAs help with entry by fostering deeper reforms? There clearly is a commitment role of GATS/FTAs in domestic competition, but how to implement is not as clear. At the same time, how can one avoid the equivalent of trade diversion in any FTAs, given the strong home bias that already exists in financial services provision (e.g., regional financial institutions may dominate cross-border banking but this may reduce the diversification and other benefits)?

\footnotetext{
${ }^{2}$ Cerutti, Dell'Ariccia and Martinez Peria 2005, study the differences between motives of foreign banks to go abroad as subsidiaries or branches. See also Gkoutzinis, 2005.
} 


\section{References}

Agénor, Pierre-Richard, 2001, "Benefits and Costs of International Financial Integration: Theory and Facts”, Policy and Research Working Paper No. 2699, The World Bank.

Allen, Franklin and Douglas Gale, 2004, “Competition and Financial Stability,” Journal of Money, Credit and Banking, 36(3) Pt. 2, 453-480.

Baele, Lieven, Ferrando, Annalisa, Hoerdahl, Peter, Krylova, Elizaveta and Monnet, Cyril, 2004, "Measuring Financial Integration in the Euro Area. European Central Bank,” (Frankfurt, Germany) Occasional Paper No. 14, May.

Barth, James, Gerard Caprio and Ross Levine, 2001, "Banking Systems Around the Globe: Do Regulation and Ownership Affect Performance and Stability?” in Frederick Mishkin (Ed). Financial Supervision and Regulation: What Works and What Doesn't? NBER, Cambridge, MA.

Barth, James, Gerard Caprio and Ross Levine, 2005, Rethinking Bank Supervision and Regulation: Until Angels Govern. Cambridge, UK: Cambridge University Press.

Baumol, William J., John C. Panzar, and Robert D. Willig, 1982, Contestable Markets and the Theory of Industry Structure, San Diego, CA: Harcourt Brace Jovanovich.

Bayraktar, Nihal and Yan Wang, 2004, "Foreign Bank Entry, Performance of Domestic Banks and Sequence of Financial Liberalization,” Policy Research Working Paper No. 3416, World Bank.

Beck, Thorsten, Asli Demirgüç-Kunt and Ross Levine, 2002, "Bank Concentration and Crises,” Mimeo, World Bank and University of Minnesota.

Beck, Thorsten, Asli Demirgüç-Kunt and Vojislav Maksimovic, 2004, "Bank Competition, Financing Constraints and Access to Credit,” Journal of Money Credit and Banking.

Bekaert, G., and C. R. Harvey, 2003, “Emerging Markets Finance,” Journal of Empirical Finance 10 (1-2): 3-56.

Bekaert, Geert, Campbell Harvey, and Christian Lundblad, 2005, “Does Financial Liberalization Spur Growth,” Journal of Financial Economics, 77, 3-56.

Berger, A.N., forthcoming, "International Comparisons of Banking Efficiency,” in Raj Aggarwal, ed., A Companion to International Business Finance.

Berger, A.N., Buch, C.M., DeLong, G., DeYoung, R., 2004, “Exporting Financial Institutions Management via Foreign Direct Investment Mergers and Acquisitions,” Journal of International Money and Finance 23:333-366.

Berger, Allen N., George R.G. Clarke, Robert Cull, Leora Klapper and Gregory F. Udell, 2005, "Corporate Governance, and Bank Performance: A Joint Analysis of the Static, Selection and Dynamic Effects of Domestic, Foreign and State Ownership,” Policy Research Working Paper No. 3632, World Bank. 
Berger, Allen N., Rebecca S. Demsetz, and Philip E. Strahan, 1999, “The Consolidation of the Financial Services Industry: Causes, Consequences, and Implications for the Future,” Journal of Banking and Finance 23 (February), 135-94.

Berger, A.N., DeYoung, R., Genay, H., Udell, G.F., 2000, “The Globalization of Finanical Institutions: Evidence from Cross-Border Banking Performance,” Brookings-Wharton Papers on Financial Services 3:23-158.

Berger, Allen N, Leora F. Klapper, and Gregory F. Udell, 2001, “The Ability of Banks to Lend to Informationally Opaque Small Businesses,” Journal of Banking and Finance 25.

Berger, Allen N., Nathan H. Miller, Mitchell A. Petersen, Raghuram Rajan, and Jeremy Stein, 2005, "Does Function Follow Organizational Form? Evidence from the Lending Practices of Large and Small Banks,” Journal of Financial Economics, 76, pp. 237-269.

Boot, Arnoud, and Anjan V. Thakor, 2000, “Can Relationship Banking Survive Competition?” Journal of Finance, 55, 2, 679-713.

Boyd, John, Gianni DeNicolo, and Smith, Forthcoming, Banking Crises and Competition, Journal of Money, Credit and Banking.

Buch, C.M., 2003, "Information versus Regulation: What Drives the International Activities of Commercial Banks?” Journal of Money, Credit and Banking 35:851-869.

Buch, C.M. DeLong, G.L., 2004, "Cross-border bank mergers: What Lures the Rare Animal?” Journal of Banking and Finance 28:2077-2102.

Buch, C. M., Carstensen, K., Schertler A, 2005, “Macroeconomic Shocks and Foreign Bank Assets,” Kiel Working Paper No. 1254, Kiel Institute for World Economics, July.

Buch, C. M., and A Lipponer, "FDI versus cross-border financial services: The Globalisation of German banks,” Discussion Paper Series 1: Studies of the Economic Research Centre, No.05/2004, Deutsche Bundesbank.

Carow, K.A., Edward Kane, and R. Narayanan, 2004, "How Have Borrowers Fared in Banking Mega-Mergers?” unpublished manuscript, Boston College.

Cetorelli, Nicola and Linda S. Goldberg, 2006, "Risks in US Bank International Exposures,” forthcoming in Federal Reserve Bank of Chicago, Cross-Border Banking Regulatory Challenges.

Centre for Economic Policy Research (CEPR), "Integration of European Banking: The Way Forward,” Monitoring European Deregulation 3, London, UK.

Cerutti, Eugenio, Giovanni Dell’Ariccia, and Maria Soledad Martinez Peria, 2005, "How Banks Go Abroad: Branches or Subsidiaries?” Unpublished manuscript, IMF and World Bank. 
Chang, C. Edward, Iftekhar Hasan, William C. Hunter, 1998, "Efficiency of multinational banks: an empirical investigation,” Applied Financial Economics, Volume 8, Number 6 / December 1.

Claessens, Stijn, 2003, Regulatory Reform and Trade Liberalization in Financial Services, 2003 in Aaditya Mattoo and Pierre Sauvé (Eds.), Domestic Regulation and Service Trade Liberalization, World Bank, Oxford University Press, Washington, D.C., 129146.

Claessens, Stijn, Aslı Demirgüç-Kunt, and Harry Huizinga, 2001, "How Does Foreign Entry Affect the Domestic Banking Market?” Journal of Banking and Finance, Vol. 25(5), 891-911.

Claessens, Stijn, Gergely Dobos, Daniela Klingebiel, and Luc Laeven, 2003, “The Growing Importance of Networks in Finance and Its Effects on Competition,” In Anna Nagurney (Ed.), Innovations in Financial and Economic Networks, Edward Elgar Publishers, Northampton, MA, USA, 110-135.

Claessens, Stijn, and Kristin Forbes, Eds, 2001, International Financial Contagion. Boston: Kluwer Academic Press.

Claessens, Stijn, and Thomas Glaessner, 1999, "Internationalization of financial services in Asia,” in James A. Hanson and Sanjay Kathuria (eds.) India. A Financial Sector for the Twenty-first Century, Oxford University Press, 369-433.

Claessens, Stijn, Daniela Klingebiel and Sergio Schmukler, 2005, “Stock Market Development and Internationalization: Do Economic Fundamentals Spur Both Similarly?” Journal of Empirical Finance, forthcoming.

Claessens, Stijn and Luc Laeven, 2004, "What Drives Banking Competition? Some International Evidence,” Journal of Money Credit and Banking 36 (3), June, Part 2, 563-583.

Claessens, Stijn and Luc Laeven, 2005, "Financial Dependence, Banking Sector Competition, and Economic Growth,” Journal of the European Economic Association, March, 3(1) 179-201.

Claessens, Stijn and Jong-Kun Lee, 2003, "Foreign Banks in Low-Income Countries: Recent Developments and Impacts, in Globalization and National Financial Systems," James Hanson, Patrick Honohan and Giovanni Majnoni (Eds.), World Bank, Washington, D.C. 109-141.

Claessens, Stijn and Enrico Perotti, 2005, “The links between finance and inequality: channels and evidence,” Background paper for the 2005 World Development Report, World Bank.

Clarke, George R.G., Robert Cull, and Maria Soledad Martinez-Peria, 2001, “Does Foreign Bank Penetration Reduce Access to Credit in Developing Countries? Evidence from Asking Borrowers,” Mimeo, Washington: The World Bank. 
Clarke, George, Cull, Robert, Maria Soledad Martinez Peria, and Susana M. Sánchez, 2003, "Foreign Bank Entry: Experience, Implications for Developing Countries, and Agenda for Further Research,” World Bank Research Observer 18 (1), 2003, 25-40.

Clarke, George, Robert Cull, Maria Soledad Martinez Peria and Susana M. Sánchez, 2005, "Bank Lending to Small Businesses in Latin America: Does Bank Origin Matter?” Journal of Money, Credit, and Banking, Vol. 37, No. 1, pp. 83-118.

Coffee, John, 1999, “The Future as History: The Prospects for Global Convergence in Corporate Governance and its Implications,” Northwestern Law Review 93, 641-708.

Dages, G.B., L.Goldberg and D. Kinney, 2000, "Foreign and domestic bank participation in emerging markets: Lessons from Mexico and Argentina,” Economic Policy Review. 6/3:17-36. Federal Reserve Bank of New York, September.

Degryse, Hans, Nancy Masschelein, and Janet Mitchell, 2005, "SMEs and Bank Lending Relationships: The Impact of Mergers,” CEPR Working Paper No. 5061.

Dell’Ariccia, Giovanni, and Robert Marquez, 2004, “Information and Bank Credit Allocation,” Journal of Financial Economics, 71, pp. 185-214.

Demirguc-Kunt, Asli, Luc Laeven, and Ross Levine, 2004, “Regulations, Market Structure, Institutions, and the Cost of Financial Intermediation,” Journal of Money, Credit, and Banking, 36(3), June, 2004, 593-622.

Demirguc-Kunt, Asli, H. Min, and Ross Levine, 1998, “Opening to Foreign Banks: Issues of Stability, Efficiency, and Growth,” in Proceedings of the Bank of Korea Conference on The Implications of Globalization of World Financial Markets, December 1998.

Detragiache, Enrica, Poonam Gupta, and Thierry Tressel, 2005, "Foreign Banks in Poor Countries: Theory and Evidence,” Working paper, IMF.

De Young, Robert and Daniel E. Nolle, 1996, "Foreign-Owned Banks in the U.S.: Buying Market Share or Earning It?” Journal of Money, Credit, and Banking 28: 622-636.

Dobson, Wendy, 2005, “Background paper - Trade in Financial Services,” Mimeo, World Bank, Trade Division.

Dobson, Wendy, and Pierre Jacquet, 1998, "Financial Services Liberalization in the WTO," Washington, DC: Institute for International Economics.

Dooley, Michael P, 2000, “A Model of Crises in Emerging Markets,” Economic Journal 10: 256-72.

Dornbusch, Rudiger, Yung Chul Park, and Stijn Claessens, 2000, "Contagion: Understanding How It Spreads,” World Bank Research Observer 15 (2):177--97.

European Central Bank, 2005, "Indicators of financial integration in the euro area," September. 
Eichengreen, Barry, 2003, Capital Flows and Crises, MIT Press, MA.

Financial Leaders Group, 1997, Barriers to trade in financial services: Case studies. London: Barclays.

Focarelli, Dario, and Alberto Pozzolo, 2003, "Where Do Banks Expand Abroad? An Empirical Investigation,” Mimeo, Bank of Italy.

Garcia-Merro, Alicia and Maria Soledad García Herrero and Martínez Pería, 2005, “The Mix of International Banks’ Foreign Claims: Determinants and Implications,” Mimeo, World Bank.

Gelos, Gaston, and Jorge Roldós, 2004, "Consolidation and Market Structure in Emerging Market Banking Systems,” Emerging Markets Review, 5, 39-59.

Giannetti, Mariassunta and Steven Ongena, 2005, "Financial Integration and Entrepreneurial Activity: Evidence from Foreign Bank Entry in Emerging Markets,” CEPR working paper 5151.

Gkoutzinis, Apostolos, "How Far is Basel from Geneva? International Regulatory Convergence and the Elimination of Barriers to International Financial Integration,” University of London, at http://ssrn.com/abstract=699781.

Goldberg, Linda S, 2002, "When Is Foreign Bank Lending to Emerging Markets Volatile?” in Preventing Currency Crises in Emerging Markets, edited by Sebastian Edwards and Jeffrey Frankel (NBER and University of Chicago Press).

Goldberg, Linda S., 2005, “The International Exposure of U.S. Banks,” NBER Working Paper 11365, Boston, MA.

de Haas, Ralph and Iman van Lelyveld, 2005, "Foreign banks and credit stability in Central and Eastern Europe,” A panel data analysis, Journal of Banking and Finance, August.

de Haas and Naaborg, 2005, Internal capital markets in Multinational Banks: Implications for European Transition Countries, mime, De Nederlandsche Bank. Amsterdam.

Haber, Stephen, and Aldo Musacchio, 2005, “Foreign Banks and the Mexican Economy, 1997-2004”, unpublished, Stanford University.

Hasan, Iftekhar and Hunter W. C., 1996, "Efficiency of Japanese Mutinational Banks in the United States,” Research in Finance 14 JAI Press: 157-173.

Hauswald, Robert and Robert Marquez, 2003, "Information Technology and Financial Services Competition,” The Review of Financial Studies, Vol. 16, No. 3, pp. 921-948.

Karceski, Jason, Steven Ongena, and David C. Smith, 2005, “The Impact of Bank Consolidation on Commercial Borrower Welfare,” Journal of Finance, 60, pp. 20432082. 
Key, Sydney, 2004, “The Doha Round and financial services negotiations,” Washington, DC: American Enterprise Institute.

Kono, Masamichi, Patrick Low, Mukela Luanaga, Aaditya Mattoo, Maika Oshidawa and Ludger Schuknecht, 1997, “Opening markets in financial services and the role of the GATS. Geneva: World Trade Organization.

Levine, Ross, 1996, “Foreign banks, financial development, and economic growth,” In International Financial Markets, ed. by Claude Barfield. Washington: American Enterprise Institute Press.

Levine, Ross and Sergio Schmukler, 2003, "Migration, Spillovers, and Trade Diversion: The Impact of Internationalization on Domestic Stock Market Liquidity,” NBER Working Paper No. 9614.

Levy-Yeyati, Eduardo, and Alejandro Micco, 2003, "Concentration and Foreign Penetration in Latin American Banking Sectors: Impact on Competition and Risk,” Research Department Working Paper No. 499, Inter-American Development Bank.

Marquez, Robert, 2002, Competition, Adverse Selection, and Information Dispersion in the Banking Industry, Review of Financial Studies, Vol. 15, No. 3, pp. 901-926.

Martinez Peria, Maria Soledad and Ashoka Mody, 2004, How Foreign Participation and Market Concentration Impact Bank Spreads: Evidence from Latin America. Journal of Money, Credit, and Banking 36:511-537.

Mian, Atif, 2003, "Foreign, Private Domestic, and Government Banks: New Evidence from Emerging Markets,” unpublished manuscript. University of Chicago.

Mian, Atif, Forthcoming, "Distance Constraints: The Limits of Foreign Lending in Poor Economies,” Journal of Finance.

Micco, Alejandro, Ugo Panizza, and Mónica Yañez, 2004, “Bank Ownership and Performance: Are Public Banks Different?” Unpublished, Inter-American Development Bank.

Obstfeld, Maurice, 1998, “The global capital market: Benefactor or menace?” Journal of Economic Perspectives. 12:4(Fall). 9-30.

Peek, Joe, Eric Rosengren and Faith Kasirye, 1999, “The Poor Performance of Foreign Bank Subsidiaries: Were the Problems Acquired or Created?” Journal of Banking and Finance. vol. 23, no. 2/4:579-604.

Petersen, Mitchell A., and Raghuram Rajan, 1995, "The Effect of Credit Market Competition on Lending Relationships,” Quarterly Journal of Economics, 110, pp. 407-443.

Rajan, Raghuram, 1992, "Insiders and Outsiders: The Choice between Informed and Arm'sLength Debt,” Journal of Finance, 47(4), pp. 1367-400. 
Sapienza, Paola, 2002, “The Effects of Banking Mergers on Loan Contracts,” Journal of Finance, 57, pp. 1891-1921.

Sauve, Pierre, 2002, "Completing the GATS framework: Safeguards, subsidies and government procurement,” In Hoekman, Bernard, Aaditya Mattoo and Philip English, eds. Development, Trade and the WTO: A Handbook, Washington, DC: World Bank.

Sorsa, P, 1997, “The GATS Agreement on financial services: A modest start to multilateral liberalization,” IMF Working Paper WP/97/55. Washington, DC: IMF.

Stein, Jeremy, 2002, "Information Production and Capital Allocation: Decentralized Versus Hierarchical Firms,” Journal of Finance, 57, pp. 1891-1921.

Vives, Xavier, 2001, “Competition in the Changing World of Banking,” Oxford Review of Economic Policy 17, 535-545. 
Hong (Rose) T. Vo

N:IStaffDir|ROSEISTIJN\Papers to be published\Competitive Implications of Cross Border Banking_Stijn Claesens_revised21606.doc 02/16/2006 10:30:00 AM 